\title{
Atlantis
}

Critical Studies in Gender, Culture \& Social Justice

Études critiques sur le genre, la culture, et la justice

\section{Pandemic Pause: A Break from Sexual Harassment. The Safe Space of Virtual Conferences}

\section{Rohini Bannerjee}

Volume 42, Number 1, 2021

URI: https://id.erudit.org/iderudit/1082017ar

DOI: https://doi.org/10.7202/1082017ar

See table of contents

Publisher(s)

Mount Saint Vincent University

ISSN

1715-0698 (digital)

Explore this journal

Cite this document

Bannerjee, R. (2021). Pandemic Pause: A Break from Sexual Harassment. The Safe Space of Virtual Conferences. Atlantis, 42(1), 63-66.

https://doi.org/10.7202/1082017ar 


\title{
Pandemic Pause: A Break from Sexual Harassment
}

\section{The Safe Space of Virtual Conferences}

\author{
by Rohini Bannerjee
}

Dr. Rohini Bannerjee (she.her.elle), born and raised in Dartmouth, Nova Scotia, Canada, daughter of immigrants from Himachal Pradesh, India, is an Associate Professor of French and Francophone Studies in the Department of Modern Languages \& Classics, Graduate Coordinator of the International Development Studies program and a Faculty Member in the Asian Studies, and Graduate Women \& Gender Studies program at Saint Mary's University, Halifax, Canada. Rohini's primary research focuses on the literatures and cultures of the Francophone Indian Ocean. When she is not teaching poetry and fiction, she attempts to write it herself. Her work has appeared with Cambridge Scholars, Caitlin Press, and Canadian Scholars and Women's Press. When not teaching or writing, Rohini serves as President of the Saint Mary's University Faculty Union and as Vice-Chair of Academic Senate. Rohini self-identifies as a woman scholar of colour.
I ndian author Arundhati Roy writes in her 2020 essay on how COVID-19 threatens India and the world that "nothing could be worse than a return to normality" (Roy 2020). I'm reminded of this line every time I think about the quotidian before March 20, 2020, the day when campus closed down and, with little strategy in hand, I loaded three boxes of books and papers into my car, uncertain of when I could return. I think about how our definition of normality has changed and perhaps evolved since we have been physically away from campus, from our offices, our colleagues, our students, and, with scholarship-related travel essentially suspended, away from meeting in person with our networks. More specifically, the new normal for conferences is virtual and for the reasons I describe below, I think this is a good thing.

I enjoy conferences-at least I used to. It is time set aside from teaching and service and from the daily demands of family life that is almost always welcome. I can step away from committee meetings, put a temporary halt on preparing lectures, and set up an automated email response. Conferences are a change of pace and of environment. I am grateful for the opportunity to focus on my research, put together a paper, read and re-read, write and edit, and eventually get on a plane and fly off somewhere outside of my every day to share my work with my peers. There, I take the time to remember that I am an active scholar and that my ideas and research are important and have impact. As a tenured, Associate Professor, now close to completing my thirteenth year at Saint Mary's University, this experience of conferences has been the norm for me. But after recent sexual harassment at a conference, one that took place before the pandemic hit, I am contemplating Arundhati Roy's statement that 
nothing could be worse than a return to normal.

The sun was shining through the glass of the beautiful convention hall for the 9 a.m. opening panel of the conference, for which I was the first speaker. The coffee was strong and gave me the jolt of energy I needed after a long day of teaching the day before, a frantic last-minute packing of luggage, a quick peek at the homework schedule for my three sons, and a bumpy flight from Halifax the previous evening. I loaded my breakfast plate with fresh fruit and a mini croissant and uploaded my PowerPoint from my USB to the conference presentation computer. I checked with IT at least twice to make sure the film clips I had spent hours to prepare and edit would actually have sound when played, and only then did I begin to work the room. Conferences are social opportunities as well as intellectual ones, and I enjoy this aspect. I chatted with colleagues who had been in Mauritius with me just three months prior and others I had not seen since graduate school.

A colleague approached. Someone I have known for nearly twenty years, someone I trusted:

"Let's take a photo," he said. "It has been ages since we have seen each other."

I put down my coffee and walked over to where he was standing. At first, our backs were facing a number of conference attendees, all hovering in front of the plethora of patisseries and pitchers of orange juice, chatting about last year's conference, about their families, the latest grants denied, the terrible weather forecast, and the number of students in their intro classes. He suggested we move away from the crowd for the photo. I thought nothing of it. Our backs were now facing a wall, with no one behind us. Another colleague, a woman, offered to take the photo.

I moved closer to him and said, "It's great to finally see you after all these years." I looked him in the eyes, not lowering my gaze. We were friends, I trusted him. He nodded and smiled. His left hand landed on my left hip and then travelled towards my backside. My mind raced. There were over 150 people in the room. He must have just let his hand slip, I thought to myself. He will pull it back up. But he didn't.

"How do I take a photo?" our colleague with the camera said. "I can't find the button on your phone."

"Just the round button," I said. My voice quivered. Press it quickly! I thought.

As she fumbled looking for the button, seconds felt like centuries, and his hand did not budge. I adjusted my stance and shifted my hips, hoping that his hand would naturally fall off my backside and he would understand where he had "mistakenly" placed it.

Thankfully, his hand fell of my body completely as our colleague called out: "Allez, un grand sourire pour moi...."

But again, his hand crept back up onto my backside and he squeezed my body, unequivocally, without hesitation and without my consent. I froze in disbelief.

"Ah voilà!" declared our colleague.

The photo was taken. The force of his palm would leave a bruise.

I lunged forward and grabbed the phone. The photo was out of focus, much like my mind at that moment. In the picture, it appears that I'm attempting to move away whilst he maintains a poker face.

I turned back to look at him. I could say nothing. I was in shock. Was I just groped by another colleague, someone I considered a friend, at a conference packed with my peers? He walked towards me, as if nothing had happened and whispered:

"I look forward to introducing you as the first speaker."

Just like that, my body was violated. I collected my thoughts and slipped into the washroom. I felt nauseous and light-headed, angry, and embarrassed. I thought of all things I should have said and done. I wanted to call my husband, my friends, my mum, everyone on my support list. But I was the first speaker at the conference, and it was nearly nine o'clock.

Walking calmly to the podium, I opened up my presentation file and did the work I had promised to do. I took questions from the floor. But when I left the microphone and returned to my table, I tuned out for the rest of the morning. During the first refreshment break, he ap- 
proached me again and I found a way to slip out of the room and call home. My voice quivered, just as it did when the photo was taken. I looked at the dress I was wearing and thought I would never choose to wear it again as it would remind me of this incident.

The rest of that day was a blur; I am unable to recall what papers were presented as my concentration levels were nil. I left the conference before the last panel was finished and went back to my hotel room. He texted to ask if I was going to the conference dinner and I declined. I wanted to say more but the fatigue of having to hide the fact I had been violated three minutes before giving my conference presentation gave me little energy. The next day he texted again, asking me if I was going to stay for the morning sessions. Again, I made an excuse that my flight was earlier than I had remembered and thought it best to get to the airport. He dared to add: "It's too bad you couldn't come over to the house and meet my wife and kids."

As I boarded the plane to return home, my thoughts were: If he could do this to me, then a 43-year-old tenured professor, then who else might have experienced this? Due to the pandemic, I have not attended a conference in person since the event described here. But I wonder, if and when I am able to attend a scholarly gathering in person, beyond mask compliance and frequent handwashing what will be $m y$ new normal?

Writing this essay was a struggle. I found creative blocks at nearly every paragraph as the personal and descriptive elements were challenging to elaborate. As soon as I realized that telling my story was empowering, however, the words arrived as needed. But what about moving forward from this? So much of our time in and out of lockdowns and staggered stages of re-opening has been about contemplation. We have been, in a sense, re-calibrating and re-assessing how things had been done before March 2020 and whether we need to see the pandemic as an opportunity. As Arundhati Roy notes, "pandemics have forced humans to break with the past and imagine their world anew. This one is no different. It is a portal, a gateway between one world and the next" (Roy 2020).

As most faculty, staff, and students are aware, many campuses have policies and initiatives around sexual harassment, including special events during welcome week, activities related to alcohol consumption and consent, connecting 2SLGBTQ+ students to support systems, and engaging with international students about risk-taking outside familiar cultural contexts. None of these policies explicitly address conferences. Many graduateschool orientation seminars talk about professional conduct as students are now assigned teaching and research assistantships, but there is no discussion about what to expect at conferences, other than presenting papers and networking for future job opportunities. Perhaps a session on the vulnerability attached to presenting one's research, in particular for those students whose identity is intersectional, might be of benefit. And within the definition of vulnerability, perhaps we need a reminder to call out unprofessional and unwanted sexual attention at conferences, thereby reinforcing the notion that conference spaces are still academic spaces.

Of course, online conferences may soon be the norm. Currently, virtual-conference organizers often remind participants to use chat functions to interact and to do so in a respectful manner. Should discussions on the safety of these online spaces also be raised and addressed with graduate students and amongst our colleagues? This is not just about internet trolls diving into online spaces and joining/bombing a Zoom meeting uninvited, but about the overall etiquette of participants in online conferences. I suggest that reminders for participants should include:

a) Keep direct messaging during a conference session to a minimum;

b) Use the same name at registration as on screen;

c) Identify your pronouns.

Let us ensure that "COVID and the Academy" remains part of conversations as we walk through this gateway toward a new normal, one that is more transparent, and, I hope, much safer.

And, by the way, I have decided that I will wear that same dress again -if it still fits! I'll wear it at my next Zoom conference and most definitely at the next in-person conference after the pandemic. Wearing that dress will remind me that his actions were his actions. While I did nothing to invite his behaviour, I will do everything I can to speak out against it. 


\section{Works Cited}

Roy, Arundhati. 2020. "The Pandemic is a Portal." Fin-

ancial Times. April 3. https://www.ft.com/content/

10d8f5e8-74eb-11ea-95fe-fcd274e920ca 